doi: https://doi.org/10.15407/dopovidi2018.01.043

УДК 621.762

\title{
Н.В. Бошицька
}

Інститут проблем матеріалознавства ім. І.М. Францевича НАН України, Київ E-mail: nata25lia@gmail.com

\section{Нанодисперсний феромагнітний порошок $\alpha-\mathrm{Fe}$, отриманий синтезом із цитратів заліза, для медичного призначення}

Представлено членом-кореспондентом НАН України О.М. Григорьєвим

Розроблено нанодисперсний феромагнітний порошок $\alpha$-Fе з комплексом фізико-хімічних властивостей (фазовий склад, висока питома поверхня, хімічна стійкість у плазмі крові і тканинній рідині), необхідних для використання в медичних ціллях. Нанодисперсний феромагнітний порошок $\alpha$-Fе отримано методом низькотемпературного $\left(350-400{ }^{\circ} \mathrm{C}\right)$ розкладання/відновлення солей цитратів у середовищі водню. Його питома поверхня 31,4 $\mathrm{m}^{2} / 2$, фізико-хімічна стабільність у плазмі крові вища порівняно із стандартними порошками

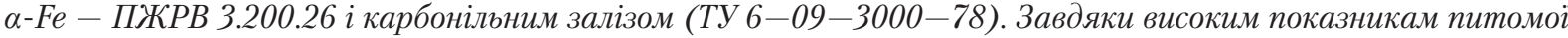
поверхні і магнітних характеристик феромагнітний порошок $\alpha$-Fе можна рекомендувати як магнітну основу для створення композиційних матеріалів медичного призначення.

Ключові слова: порошок заліза, феромагнітний порошок, стабільність.

Останніми роками дедалі ширше застосування в медицині - як магнітної основи для перенесення низки лікарських препаратів - знаходять композиційні нанорозмірні магнітні порошкові матеріали. Безперечною перевагою використання таких композиційних лікарських систем є підтримання належного рівня локальних концентрацій терапевтичних препаратів у зоні ураження за умов істотного зниження обсягу їх загального дозування та зменшення ефектів побічної дії на організм людини у цілому [1, 2].

Перші повідомлення про спрямовану доставку лікарських препаратів із використанням нанодисперсного оксиду заліза датуються 1965 р. [3]. Пізніші ж дослідження in vivo [4, 5] показали, що використання магнітних суспензій на основі заліза як магнітної основи для локалізації та перенесення хіміотерапевтичних засобів в онкологічній практиці забезпечує необхідну концентрацію і пролонговану дію лікарського препарату в зоні ураження.

Відомо [6, 7], що нанорозмірні частинки заліза є біологічно активними агентами і залежно від їх кількості, хімічного складу та наявності домішок вони можуть активувати або ж, навпаки, пригнічувати ті чи інші функції життєво важливих органів. Тому при введенні в організм певної кількості порошку заліза необхідно, передусім, мати чітке уявлення про його поведінку в таких біосередовищах, як кров, тканинні й міжклітинні рідини та лімфа.

(C) Н.В. Бошицька, 2018 
Метою дослідження є розробка і отримання нанодисперсного феромагнітного порошку $\alpha$-Fе з комплексом фізико-хімічних властивостей (фазовий склад, висока питома поверхня, хімічна стійкість у плазмі крові й тканинній рідині), необхідних для використання в медичних цілях.

Основні матеріали та методи досліджень. Основними об'єктами досліджень були порошки:

заліза різного фазового складу та дисперсності, отримані розкладом/відновленням солей цитратів заліза у відновному середовищі водню;

крупнодисперсного заліза марки ПЖРВ 3.200.26 (ГОСТ 9849-86), одержаного методом розпилення водою в умовах високих тисків (Казенний завод порошкової металургії, Бровари, Україна);

карбонільного заліза (ТУ 6-09-3000-78), отриманого термічним розкладанням пентакарбонілу заліза згідно з рівнянням $\mathrm{Fe}(\mathrm{CO})_{5}=\mathrm{Fe}+5 \mathrm{CO}$.

На відміну від традиційних методів отримання порошків заліза шляхом термічного розкладу його солей [8], у дослідженні для синтезу нанодисперсного порошку на основі заліза було використано комбінацію методу розкладання і відновлення цитратної солі заліза $\mathrm{Fe}_{3}\left\{\mathrm{C}_{3} \mathrm{H}_{5}(\mathrm{O})(\mathrm{COO})_{3}\right\}_{2}$ у відновному середовищі водню і модифікованої методики подальшої пролонгованої пасивації поверхні утвореного порошку заліза шляхом контрольованого заміщення захисного середовища водню повітряною сумішшю. Розкладання солі цитрату заліза проводили в атмосфері водню в діапазоні температур $250-450{ }^{\circ} \mathrm{C}$ у спеціально сконструйованому захисному герметичному муфелі, в якому забезпечували створення контрольованого газового середовища.

Рентгеноструктурні дослідження отриманих порошків проводили за допомогою рентгенівського дифрактометра ДРОН-3.0 в Со $\kappa_{\alpha}$-випромінюванні [9].

Виміри магнітних характеристик порошків - питомої намагніченості насичення, залишкової індукції, коерцитивної сили - здійснювали з використанням балістичного магнітометра в діапазоні полів до 800 кА/м при кімнатній температурі [10].

Електронно-мікроскопічні дослідження порошків проведені на сканувальному електронному мікроскопі JSM 6360 LA, з системою рентгеноспектрального енергодисперсійного мікроаналізу JED-2200, прискорювальна напруга становила 15 кВ, діаметр електронного зонда - 4 нм [11].

Результати досліджень і їх обговорення. 3 метою контролю за фазовим складом та дисперсністю одержаного порошку відбирали зразки синтезованого продукту при 250, 300, 325, 400 і $450{ }^{\circ} \mathrm{C}$. Температурний інтервал експерименту в $50{ }^{\circ} \mathrm{C}$ обрано для точного підбору та оптимізації умов синтезу нанорозмірних порошків заліза, які за своїми розмірами, морфологією частинок, фазовим та хімічним складом можуть бути використані в медичних цілях.

Результати рентгенофазового аналізу зразків, одержаних у діапазоні температур 250$450{ }^{\circ} \mathrm{C}$ шляхом розкладання / відновлення цитратних солей у водні, показали, що порошки, синтезовані при 250 і $300{ }^{\circ} \mathrm{C}$, містять тільки кристалічну фазу оксикарбіду заліза $\mathrm{FeC}_{2} \mathrm{O}_{4}$ (табл. 1).

Згідно з даними хімічного аналізу кількість заліза в порошках, синтезованих при $250{ }^{\circ} \mathrm{C}$, становить 59,4 \% (мас.), а вуглецю - 11,84 \% (мас.) (табл. 2). В порошках, синтезованих при $30{ }^{\circ} \mathrm{C}$, кількість заліза збільшується в середньому до 63,07 \% (мас.), а при $325{ }^{\circ} \mathrm{C}$ - збіль- 
шується неістотно порівняно зі зразками, одержаними під впливом нижчих температур, i становить в середньому 72,41 \% (мас.) (див. табл. 2).

За результатами рентгенофазового аналізу, порошок, синтезований при $325^{\circ} \mathrm{C}$, містить фази $\mathrm{FeC}_{2} \mathrm{O}_{4}$, $\alpha$-Fe i $\mathrm{Fe}_{3} \mathrm{O}_{4} .3$ підвищенням температури синтезу до $350{ }^{\circ} \mathrm{C}$ спостерігається зменшення на рентгенограмах порошків кількості кристалічної фази оксикарбіду заліза $\mathrm{FeC}_{2} \mathrm{O}_{4}$ (див. табл. 1).

Проведено електронно-мікроскопічні дослідження мікроструктури одержаних порошків у діапазоні збільшень ×1000 та визначено хімічний склад порошків на довільно обраних ділянках дослідних зразків (рис. 1). Показано, що порошок, одержаний при $400{ }^{\circ} \mathrm{C}, \epsilon$ пористою структурою з розмірами деяких структурних елементів $\sim 0,1-0,2$ мкм (див. рис.1), близькими до розмірів областей когерентного розсіювання (ОКР), виміряних за допомогою рентгенівського методу (див. табл.1). Кількість заліза в зразку більша порівняно з порошками, отриманими під впливом нижчих температур, і становить у середньому 97,58 \% (мас.). Кількість загального вуглецю в порошках знижується зі збільшенням температури синтезу і в цьому порошку становить 0,65 \% (мас.) (див. табл. 2).

Згідно з даними рентгенофазового аналізу, порошки, синтезовані при 400 i $450{ }^{\circ} \mathrm{C}$, складаються тільки з кристалічної фази $\alpha$-Fе (див. табл. 1).

Таблиия 1. Фазовий склад і розмір областей когерентного розсіювання $\left(\boldsymbol{D}_{\text {окр }}\right)$ порошків, одержаних синтезом із цитратів заліза

\begin{tabular}{|c|c|c|c|}
\hline Режим синтезу, $t,{ }^{\circ} \mathrm{C}, 2$ год & Фазовий склад, \% (мас.) & Вміст фаз, \% & $D_{\text {окр }}$, нм \\
\hline \multirow{2}{*}{250} & $\mathrm{FeC}_{2} \mathrm{O}_{4}$ & 100 & 50 \\
300 & $\mathrm{FeC}_{2} \mathrm{O}_{4}$ & 100 & 50 \\
325 & $\mathrm{FeC}_{2} \mathrm{O}_{4}$ & 70 & 60 \\
& $\alpha-\mathrm{Fe}$ & 10 & 50 \\
\multirow{2}{3}{350} & $\mathrm{Fe}_{3} \mathrm{O}_{4}$ & 20 & 150 \\
& $\alpha-\mathrm{Fe}$ & 98 & - \\
400 & $\mathrm{Fe}_{3} \mathrm{O}_{4}$ & 2 & 180 \\
450 & $\alpha-\mathrm{Fe}$ & 100 & 1100 \\
\hline
\end{tabular}

Таблиия 2. Фазовий та поелементний склад (\% (мас.)) і питома поверхня (м²/г) порошків заліза, синтезованих при різних температурах

\begin{tabular}{|c|c|c|c|c|c|}
\hline$t,{ }^{\circ} \mathrm{C}$ & $\mathrm{C}$ & $\mathrm{O}$ & $\mathrm{Fe}$ & Інші домішки & Питома поверхня \\
\hline 250 & 11,84 & 26,43 & 59,40 & 1,33 & 9,88 \\
300 & 9,85 & 22,56 & 63,07 & 4,52 & 15,07 \\
325 & 6,10 & 19,64 & 72,41 & 1,85 & 28,0 \\
350 & 1,65 & 4,50 & 91,72 & 2,13 & 30,3 \\
400 & 0,65 & 2,44 & 97,58 & 2,33 & 31,4 \\
450 & 0,67 & 1,99 & 96,15 & 1,19 & 30,7 \\
\hline
\end{tabular}




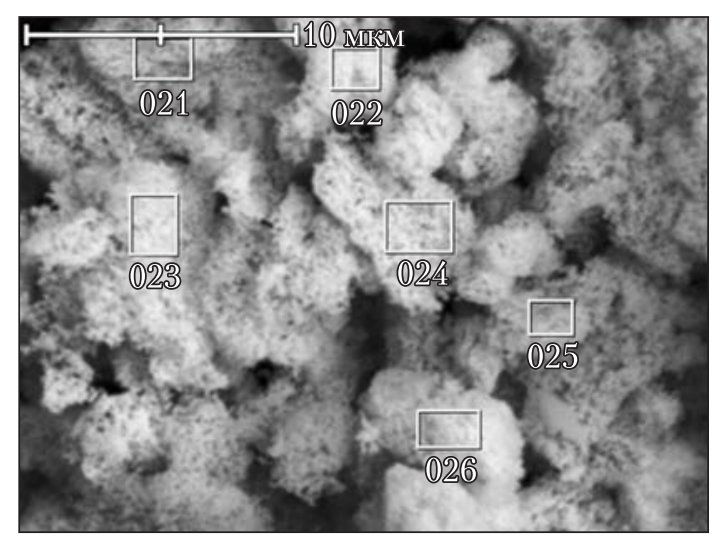

Puc. 1. Мікрофотографія та хімічний склад на довільно вибраних ділянках зразка порошку заліза, одержаного синтезом із солей цитрату заліза при $400{ }^{\circ} \mathrm{C}$ (збільшення $\times 3000$ )
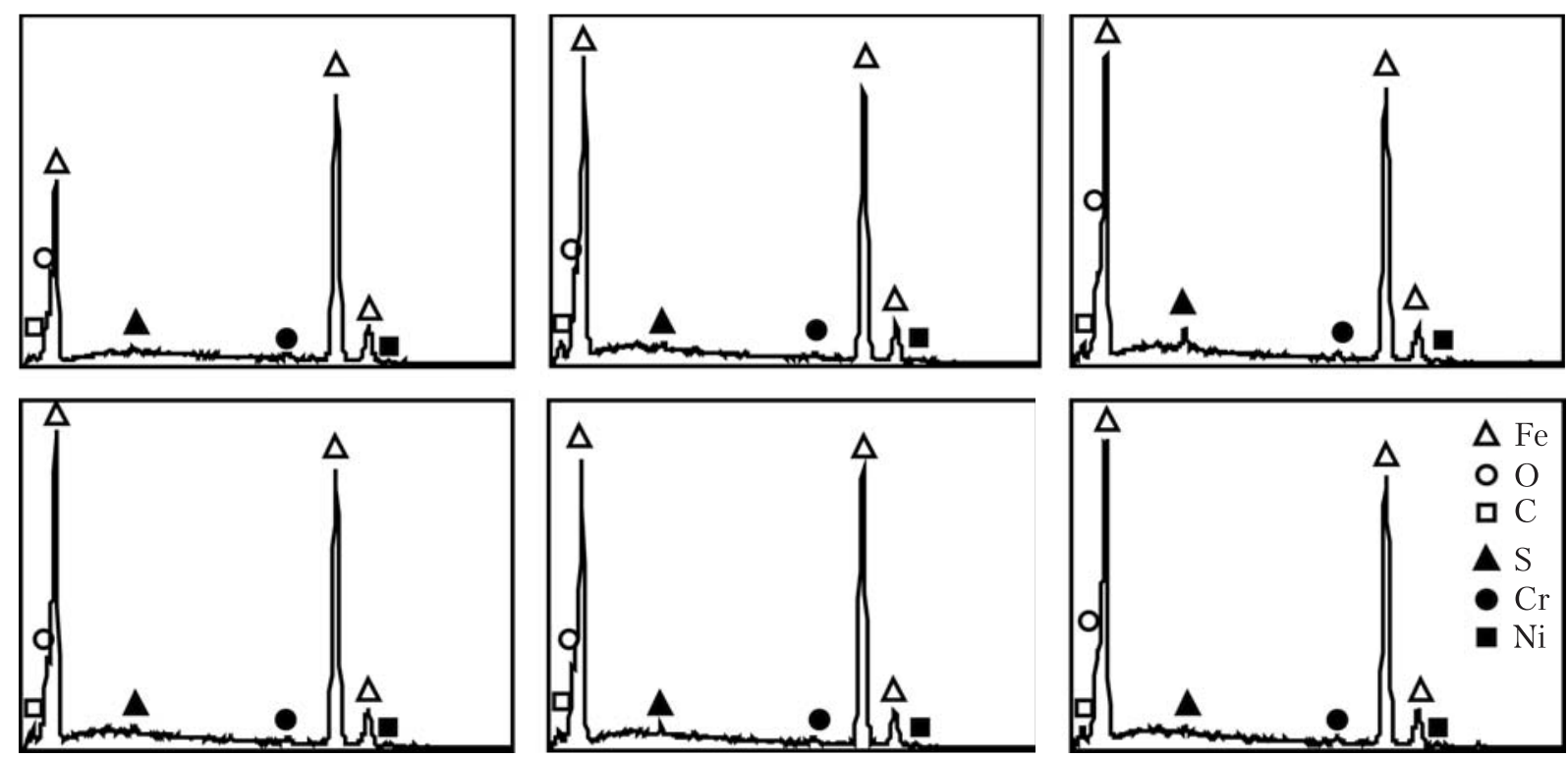

\begin{tabular}{|c|c|c|c|c|c|c|c|}
\hline № & $\mathrm{C}$ & $\mathrm{O}$ & $\mathrm{S}$ & $\mathrm{Cr}$ & $\mathrm{Fe}$ & $\mathrm{Ni}$ & Сума \\
\hline 021 & 0,42 & 1,47 & 0,28 & 0,98 & 96,28 & 0,56 & 100 \\
022 & 0,71 & 2,90 & 0,31 & 0,77 & 94,65 & 0,67 & 100 \\
023 & 0,85 & 2,81 & 1,18 & 1,01 & 93,51 & 0,64 & 100 \\
024 & 0,71 & 2,43 & 0,39 & 0,80 & 94,98 & 0,69 & 100 \\
025 & 0,69 & 2,52 & 0,40 & 0,77 & 95,30 & 0,33 & 100 \\
026 & 0,50 & 2,63 & 0,43 & 0,85 & 95,07 & 0,52 & 100 \\
\hline
\end{tabular}

Встановлено, що з підвищенням температури синтезу кількість оксикарбіду $\mathrm{FeC}_{2} \mathrm{O}_{4}$ зменшується, тоді як $\alpha$-Fе збільшується, що зумовлено інтенсифікацією дифузійних процесів, які призводять до формування наведених кристалічних фаз (див. табл. 1).

Питому поверхню порошків, синтезованих при різних температурах, визначали газохроматографічним методом за тепловою десорбцією азоту [12]. Як видно з наведених даних (див. табл. 2), питома поверхня порошків зростає зі збільшенням температури розкладання 
Puc. 2. Залежність питомої намагнітизованості порошків, одержаних синтезом із солей цитрату заліза, від напруги магнітного поля при температурах $\left({ }^{\circ} \mathrm{C}\right): 1-250$; $2-300 ; 3-325 ; 4-400 ; 5-450$

з утворенням декількох фаз і досягає максимальних значень 31,4 та 30,7 м²/г з переходом до однофазної системи при 400 і $450{ }^{\circ} \mathrm{C}$ відповідно.

Залежність питомої намагніченості порошків, отриманих шляхом розкладання / віднов-

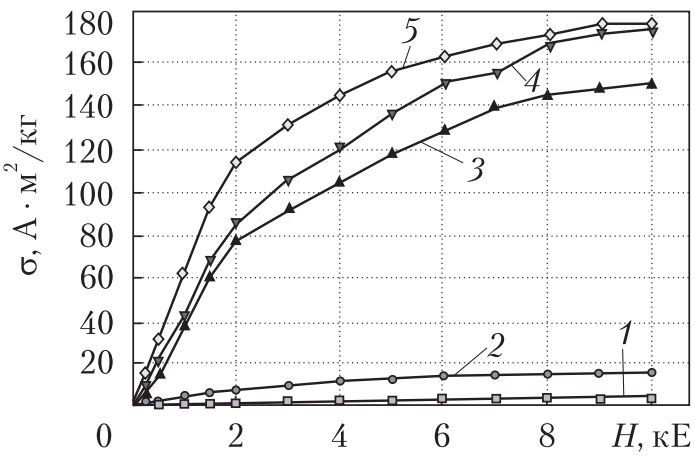
лення солей цитрату заліза в діапазоні температур 250, 300, 325, 400 і $450{ }^{\circ} \mathrm{C}$, від напруги магнітного поля показано на рис. 2. Побудовані криві мають вигляд, характерний для феромагнітних матеріалів, за винятком порошків, синтезованих при 250 і $300{ }^{\circ} \mathrm{C}$ (див. рис. 2 , криві 2,3$)$, які не містять феромагнітних фаз. Характерно, що з підвищенням температури синтезу криві залежності питомої намагнітизованості зміщуються вгору за віссю ординат у бік збільшення їхніх абсолютних значень (що також відповідає зростанню величини питомої намагніченості одержаних порошків).

Цей експериментальний факт повністю узгоджується з результатами рентгенофазового аналізу і зумовлений збільшенням кількості феромагнітної $\alpha$-фази в порошках з підвищенням температури синтезу (див. табл. 1). Показано, що зі збільшенням температури синтезу також підвищується рівень залишкової індукції $B_{r}$ (табл. 3) з тих самих причин [13]. Коерцитивна сила $H_{c}$, пов'язана з розмірами частинок порошків, збільшується з підвищенням температури синтезу до $35^{\circ} \mathrm{C}$ (розмір ОКР 150 нм) і досягає максимального значення $120 \mathrm{E}$, а при $400{ }^{\circ} \mathrm{C}$, коли відзначається незначне збільшення розміру частинок (розмір ОКР 180 нм), зменшується і становить 65 Е. Залишкова індукція $B_{r}$ найвища при $400{ }^{\circ} \mathrm{C}$, коли в системі наявна тільки нанорозмірна фаза $\alpha$-Fe.

3 подальшим підвищенням температури синтезу до $450{ }^{\circ} \mathrm{C}$ значення питомої намагнітизованості $\sigma_{S}$ та залишкової індукції $B_{r}$ синтезованих порошків, пов’язані з вмістом у них феромагнітної фази, залишаються практично без змін, а коерцитивна сила $H_{c}$ продовжує зменшуватися через збільшення розміру частинок порошків. Таким чином, порошок, синтезований при 400 들 має найвищі магнітні характеристики (див. табл. 3).

Результати поелементного аналізу (див. табл. 2) свідчать про те, що вміст основних елементів в одержаних порошках залежить від температури синтезу: чим вона вища, тим менше в порошках вуглецю та кисню і тим більше заліза. Цей висновок повністю узгоджується з результатами рентгенофазового аналізу й пов’язаний із розкладом оксидів і карбідів заліза та збільшенням кількості фази $\alpha$-Fе у порошках (див. табл. 1).

Як вже зазначалося, нанодисперсний порошок $\alpha-\mathrm{Fe}$, отриманий шляхом розкладання/ відновлення цитратних солей при $400{ }^{\circ} \mathrm{C}$ у середовищі водню, являє собою пористу структуру з розмірами структурних елементів $\sim 0,1-0,2$ мкм, близькими до розмірів областей когерентного розсіювання $\left(D_{\text {окр }}\right)$, обчислених за допомогою рентгенівського методу (див. рис. 1, табл. 1). В роботі досліджено інтенсивність взаємодії порошку $\alpha$-Fе з неорганічними та біологічними середовищами: плазмою крові й фізіологічними розчинами 0,9 \% $\mathrm{NaCl}$ та Рінгера. 
Методами рентгенофазового аналізу доведено, що синтезований порошок кристалічної фази $\alpha$-Fe після взаємодії з фізіологічними розчинами 0,9 \% $\mathrm{NaCl}$ та Рінгера повністю окиснюється, лінії $\alpha$-Fе на дифрактограмах зникають, у твердих залишках виявляється лише фаза $\mathrm{Fe}_{3} \mathrm{O}_{4}$ (рис. 3, б, в). Після взаємодії з плазмою крові людини порошок, що складається з феромагнітної $\alpha$-фази заліза, окиснюється не повністю, на дифрактограмах присутні лінії $\alpha$-фази $\mathrm{Fe}, \mathrm{Fe}_{3} \mathrm{O}_{4}$ та $\mathrm{FeO}$ у співвідношенні 59 : 39 : 2 відповідно (див. рис. 3 , г).

Проведено порівняльний аналіз нанодисперсного порошку $\alpha$-Fe 3 порошками крупнодисперсного заліза марки ПЖРВ 3.200.26 (ГОСТ 9849-86), одержаного методом розпилення водою в умовах високих тисків (Казенний завод порошкової металургії, Бровари, Україна), та карбонільного заліза (ТУ 6-09-3000-78), отриманого термічним розкладанням пентакарбонілу заліза за рівнянням $\mathrm{Fe}(\mathrm{CO})_{5}=\mathrm{Fe}+5 \mathrm{CO}$. Дані хімічного аналізу фільтратів біологічних та неорганічних середовищ свідчать про те, що досліджуваний порошок $\alpha$-Fe $\left(\mathrm{H}_{2}\right)$ розчинюється в плазмі крові з меншою інтенсивністю, ніж крупнодисперсні порошки (табл. 4), виділяючи у фільтрат 94,2 мг/100 мл заліза, тоді як крупнодисперсні порошки марки ПЖРВ 3.200.26 та карбонільного заліза виділяють у фільтрат плазми крові 130,25 та 183,13 мг/100 мл відповідно.

Можна припустити, що нанодисперсний порошок $\alpha$-Fe активно взаємодіє 3 плазмою крові людини, утворюючи з присутніми в ній білками колоїдні комплекси, які перешкоджають процесам подальшого розчинення порошку. Крупнодисперсні порошки, розмір частинок яких лежить в діапазоні 200-240 мкм, не здатні утворювати колоїдні міцели через власні крупні розміри; вони розчиняються в плазмі крові, взаємодіючи з присутніми в ній водою, солями тощо.

Методом електронної мікроскопії проведено порівняльне дослідження морфології частинок порошку $\alpha$-Fе вихідного та після взаємодії з фізіологічними розчинами і плазмою крові (рис. 4). Показано, що вихідний порошок, який складається з конгломератів розмірами в діапазоні 2,0-2,5 мкм (див. рис. 4, $a$ ), після взаємодії з фізіологічними розчинами подрібнюється, поверхня стає пухкою, розмір конгломератів становить близько 0,5-0,1 мкм (б). Після взаємодії з плазмою крові частинки порошку практично зберігають свою форму, розмір конгломератів знаходиться в діапазоні 1,0-2,0 мкм (див. рис. 4, в).

Таким чином, низькотемпературний розклад цитратної солізаліза $\mathrm{Fe}_{3}\left\{\mathrm{C}_{3} \mathrm{H}_{5}(\mathrm{O})(\mathrm{COO})_{3}\right\}_{2}$ у відновному середовищі водню за певних технологічних умов дає можливість одержати на-

Таблиия 3. Магнітні властивості порошків, одержаних шляхом розкладання/відновлення цитратів заліза

\begin{tabular}{|c|c|c|c|}
\hline Режим синтезу, $t,{ }^{\circ} \mathrm{C}, 2$ год & $\sigma_{S}, \mathrm{~A} \cdot \mathrm{M}^{2} /$ кг & $H_{c}, \mathrm{E}$ & $B_{r}$, Гс \\
\hline 250 & 0,5 & - & - \\
300 & 4,1 & - & - \\
325 & 15,8 & 20 & 68,8 \\
350 & 150 & 120 & 1522 \\
400 & 177,6 & 100 & 1599 \\
450 & 179,6 & 65 & \\
\hline
\end{tabular}



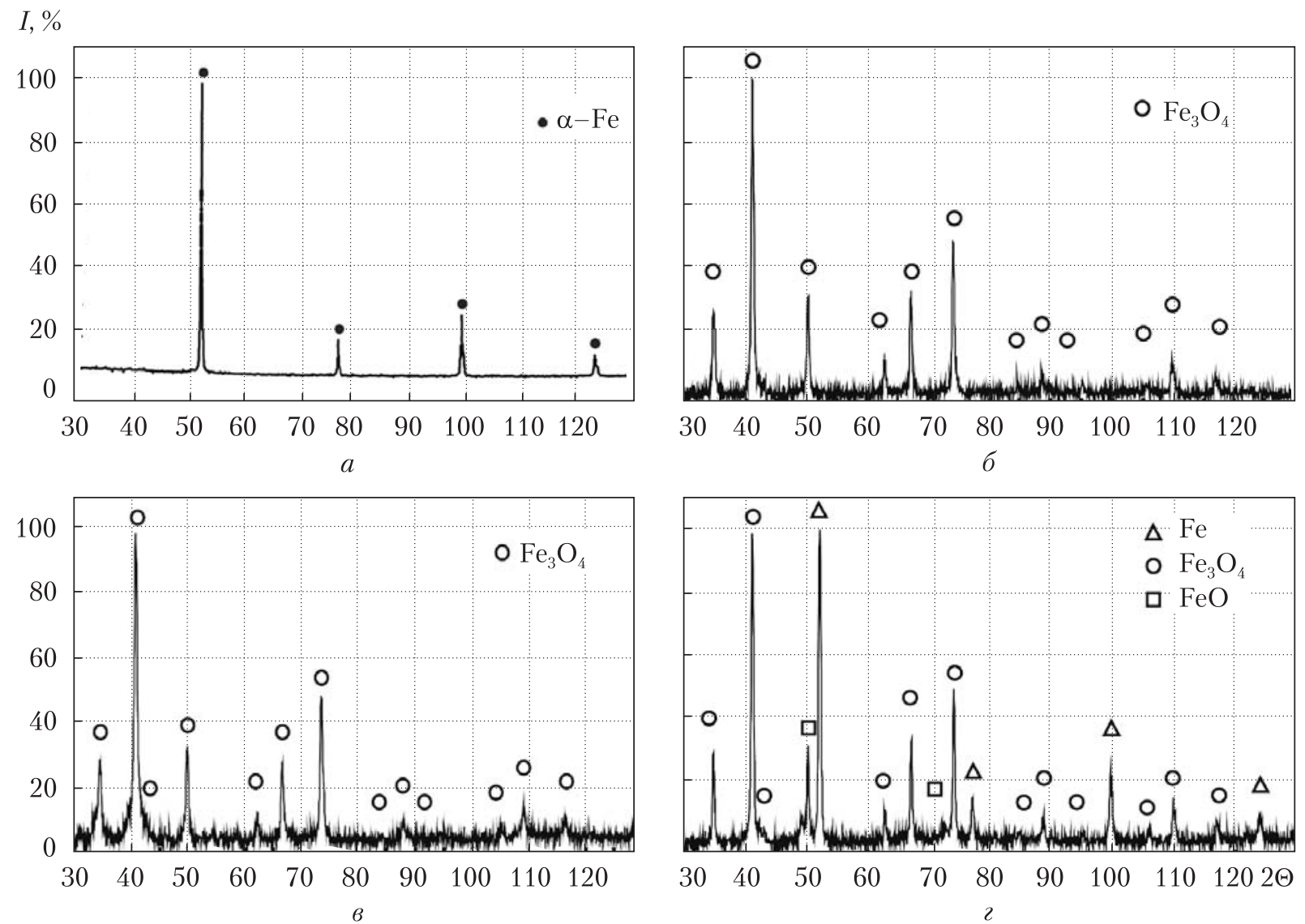

Puc. 3. Рентгенограми порошку, отриманого розкладанням/відновленням цитратів заліза при $400{ }^{\circ} \mathrm{C}$ у середовищі водню: $a-$ вихідного; 6, в - після взаємодії з розчинами $0,9 \% \mathrm{NaCl}$ та Рінгера відповідно; після взаємодії з плазмою крові людини

Таблиц, 4. Кількість загального заліза у фільтратах плазми крові та неорганічних середовищах після взаємодії з досліджуваними порошками

\begin{tabular}{|l|l|c|}
\hline \multicolumn{1}{|c|}{ Порошок } & Середовище & $\mathrm{Fe}_{\text {заг }} \mathrm{y}$ фільтраті, мг $/ 100$ мл \\
\hline \multirow{2}{*}{-Fe, синтез з цитратів, $t-400{ }^{\circ} \mathrm{C}\left(\mathrm{H}_{2}\right)$} & Рінгера & 47,3 \\
& $0,9 \% \mathrm{NaCl}$ & 38,1 \\
\multirow{2}{*}{$\alpha$-Fe, марка ПжРВ 3.200.26 } & Плазма крові & 94,2 \\
& Рінгера & 39,89 \\
\multirow{2}{*}{-Fe, карбонільне залізо } & $0,9 \% \mathrm{NaCl}$ & 30,2 \\
& Плазма крові & 130,25 \\
& Рінгера & 31,09 \\
& $0,9 \% \mathrm{NaCl}$ & 26,95 \\
& Плазма крові & 183,13 \\
\hline
\end{tabular}



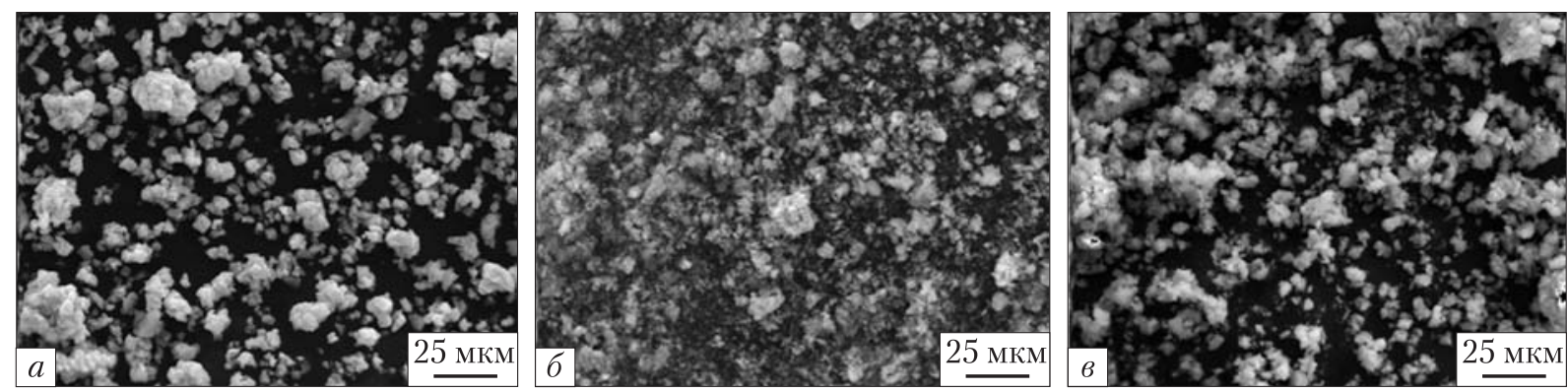

Puc. 4. Мікрофотографії порошків заліза, отриманих синтезом з цитратів при $400^{\circ} \mathrm{C}\left(\mathrm{H}_{2}\right)$ : $a-$ вихідного; $\sigma$ - після взаємодії з 0,9\% NaCl; в - після взаємодії з плазмою крові (збільшення ×600)

нодисперсний порошок заліза. В процесі синтезу порошків з підвищенням температури в діапазоні $250-450{ }^{\circ} \mathrm{C}$ відбувається збільшення в них кількості феромагнітної $\alpha$-фази. Згідно 3 даними рентгенофазового аналізу, порошки, синтезовані при 350, 400 і $450{ }^{\circ} \mathrm{C}$, складаються лише з кристалічної фази $\alpha$-Fe. Підвищення ж температури синтезу порошків заліза зумовлює зростання величин їх питомої намагнітизованості і залишкової індукції (що зумовлено збільшенням кількості феромагнітної $\alpha$-фази). Методом низькотемпературного $\left(400{ }^{\circ} \mathrm{C}\right)$ розкладання/відновлення солей цитратів у середовищі водню отримано нанодисперсний феромагнітний порошок $\alpha$-Fе з питомою поверхнею $31,4 \mathrm{~m}^{2} /$, фізико-хімічна стабільність якого в плазмі крові вища порівняно зі стандартними порошками $\alpha$-Fe - ПЖРВ 3.200.26 та карбонільним залізом (ТУ 6-09-3000-78). Зважаючи на високі значення питомої поверхні та магнітні характеристики феромагнітний порошок $\alpha$-Fе можна рекомендувати як магнітну основу для створення композиційних матеріалів медичного призначення.

\section{ЦИТОВАНА ЛІТЕРАТУРА}

1. Митькина В. А. Химическая трансформация магнитных носителей лекарственных препаратов в модельных растворах и плазме крови. Сиб. онкол. журн. 2009. Прил. № 1. С. 136-137.

2. Рокко М., Уильямс Р., Аливисатос П. Нанотехнология в ближайшем десятилетии. Прогноз направления исследований. Москва: Мир, 2002. 158 с.

3. Gilchrist R.K., Shorey W.D., Hanselman R., De Peyster F.A, Yang J., Medal R. Effects of electromagnetic heating on internal viscera: a preliminary to the treatment of human tumors. Ann. Surg. 1965. 161, № 6 . P. 890-895.

4. Andreas S., Lubbe M., Alexiou C., Bergemann C. Clinical applications of magnetic drug targeting. J. Surg. Res. 2001. 95, № 2. P. 200-206.

5. Shapiro B., Probst R., Potts H., Diver D., Lubbe A. Control to concentrate drug-coated magnetic particles to deep-tissue tumors for targeted cancer chemotherapy. Proceeding of the 46th IEEE Conference on Decigion and Control. New Orleans: LA, 2007. P. 3-30.

6. Jianwei Z., Jianming W., Tao T., Gao L., Haibin C., Shengquan Z. Experimental study on magnetic drug targeting in treating cholangiocarcinoma based on internal magnetic fields. Chin.-Ger.J. Clin. Oncol. 2006. 5, № 5. P. 336-338.

7. Moroz S.K., Jones B.N. Numerical analysis of ferromagnetic embolisation hyperthermia for liver tumour therapy.J. Surg. Oncol. 2002. 80, № 6. P. 149.

8. Звездина Н.Д., Мартынова Л.Е., Звездин К.А. Новые инструменты в медицине и биологии: использование магнитных наночастиц. Нанотехника. 2007. 2, № 10. С. 33-42.

9. Лиопо В.А., Гимпель Н.Н., Васильев Е.К. Рентгеновский фазовый анализ с использованием базы данных. Применение рентгеновских лучей в науке и технике. Иркутск: ИГУ, 1995. С. 125-131. 
10. Чечерников В.И. Магнитные измерения. Москва: Изд-во Моск. ун-та, 1969. 388 с.

11. Hayat M.A. Principles and techniques of electron microscopy: biological applications. Cambridge: Cambridge Univ. Press, 2000. 65 p.

12. Паничкина В.В., Уварова И.В. Методы контроля дисперсности и удельной поверхности металлических порошков. Киев: Наук. думка, 1973. Т. 1-2. 167c.

13. Толочко О.В., Ли Д.-В., Чой Ч.-Дж., Ким Д., Ариф М. Структура и магнитные свойства наночастиц на основе железа в оксидной оболочке. Письма в ЖТФ. 2005. 31, вып. 18. С. 30-36.

Надійшло до редакції 15.09.2017

\section{REFERENSES}

1. Mytkina, V. A. (2009). Chemical transformation of magnetic carriers of medicinal preparations in model solutions and plasma of blood. Sibirskiy oncol. zhurn., Suppl. 1, pp. 136-137 (in Russian).

2. Rokko, M., Williams, R. \& Allivisatos, P. (2002). Nanotechnology in the nearest decade. Prognosis of direction of researches. Moscow: Mir (in Russian).

3. Gilchrist, R.K., Shorey, W.D., Hanselman, R.C., De Peyster, F. A., Yang, J. \& Medal, R. (1965). Effects of electromagnetic heating on internal viscera a preliminary to the treatment of human tumors. Ann. Surg., 161, No. 6, pp. 890-895.

4. Andreas, S., Lubbe, M., Alexiou, C. \& Bergemann, C. (2001). Clinical applications of magnetic drug targeting. J. Surg. Res., 95, No. 2, pp. 200-206.

5. Shapiro, B., Probst, R., Potts, H., Diver, D. \& Lubbe, A. (2007). Control to concentrate drug-coated magnetic particles to deep-tissue tumors for targeted cancer. Proceeding of 46th IEEE Conference on Decigion and Control (pp. 3-30). New Orleans.

6. Jianwei, Z., Jianming, W., Tao, T., Gao, L., Haibin, C. \& Shengquan, Z. (2006). Experimental study on magnetic drug targeting in treating cholangiocarcinoma based on internal magnetic fields. Chin.-Ger. J. Clin. Oncol., 5, No. 5, pp. 336-338.

7. Moroz, S. K. \& Jones, B. N. (2002). Numerical analysis of ferromagnetic embolisation hyperthermia for liver tumour therapy. J. Surg. Oncol., 80, No. 6, pp. 149.

8. Zvezdina, N. D., Martynova, L.E. \& Zvezdin, K. A. (2007). New instruments are in medicine and biology : the use of magnetic nanoparticles. Nanotekhnika, 2, No. 10, pp. 33-42 (in Russian).

9. Liopo, V. A., Gympel, N. N. \& Vasyliev, E. K. (1995). X-rayed phase analysis with the use of database. In Application of x-rays is in science and technique (pp. 125-131). Irkutsk: IGV (in Russian).

10. Chechernikov, V. I. (1969). Magnetic measuring. Moscow: Izd-vo Mosk. Un-ta (in Russian).

11. Hayat, M. A. (2000). Principles and techniques of electron microscopy: biological applications. Cambridge: Cambridge Univ. Press.

12. Panichkina, V. V. \& Uvarova, I. V. (1973). Methods of control of dispersion and specific surface of metallic powders. Vol. 1-2. Kiev: Naukova Dumka (in Russian).

13. Tolochko, O. V., Lee, D. W., Choi, C.-J., Kim, D. \& Arif, M. (2005). Structure and magnetic properties of iron based nanoparticles with oxide shells. Tech. Physs. Lett., 31, No. 9, pp. 779-781.

Received 15.09.2017

\section{Н.В. Бошищкая}

Институт проблем материаловедения им. И.Н. Францевича НАН Украины, Киев

E-mail:nata25lia@gmail.com

\section{НАНОДИСПЕРСНЫЙ ФЕРРОМАГНИТНЫЙ ПОРОШОК $\alpha$-Fe, ПОЛУЧЕННЫЙ СИНТЕЗОМ ИЗ ЦИТРАТОВ ЖЕЛЕЗА, ДЛЯ МЕДИЦИНСКОГО ПРИМЕНЕНИЯ}

Разработан нанодисперсный феромагнитный порошок $\alpha$-Fе с комплексом физико-химических свойств (фазовый состав, высокая удельная поверхность, химическая стойкость в плазме крови и тканевой жидкости, активное растворение в желудочном соке, химическая чистота), необходимых для использования в медицинских целях. Нанодисперсный ферромагнитный порошок $\alpha$-Fе получен методом низкотемпера- 
турного $\left(350-400{ }^{\circ} \mathrm{C}\right)$ разложения/восстановления солей цитратов в среде водорода. Его удельная поверхность составляет $31,4 \mathrm{~m}^{2} /$, физико-химическая стабильность в плазме крови выше по сравнению со стандартными порошками $\alpha-\mathrm{Fe}-$ ПЖРВ 3.200 .26 и карбонильным железом (ТУ 6-09-3000-78). Благодаря высоким показателям удельной поверхности и магнитных характеристик ферромагнитный порошок $\alpha$-Fе можно рекомендовать в качестве магнитной основы при создании композиционных материалов медицинского назначения.

Ключевые слова: порошок железа, ферромагнитный порошок, стабильность.

\section{N.V. Boshytska}

Frantsevich Institute for Problems of Material Science of the NAS of Ukraine, Kiev E-mail: nata25lia@gmail.com

\section{NANODISPERSIBLE FERROMAGNETIC POWDER $\alpha$-Fe SYNTHESIZED FROM CITRATES OF IRON FOR MEDICAL APPLICATIONS}

A nanodispersible ferromagnetic powder $\alpha$-Fe with the complex of physical and chemical properties (phase composition, high specific surface, chemical stability in plasma of blood and tissue liquid, active dissolution in gastric juice, chemical cleanness) necessary for the use in medical aims is created. The method of low-temperature (350$400{ }^{\circ} \mathrm{C}$ ) decomposition/renewal of salts of citrates in the environment of hydrogen allowed us to get a nanodispersible ferromagnetic powder $\alpha$-Fe with the specific surface of $31.4 \mathrm{~m}^{2} / \mathrm{g}$. Its physical and chemical stability in plasma of blood is higher, as compared to standard powders $\alpha-\mathrm{Fe} 3.200 .26$ and carbonic-iron (6-09-3000-78). The high specific surface and magnetic properties allow us to recommend a ferromagnetic powder $\alpha$-Fe as a magnetic basis in the creation of composition materials for medical applications.

Keywords: powder of iron, ferromagnetic powder, stability. 